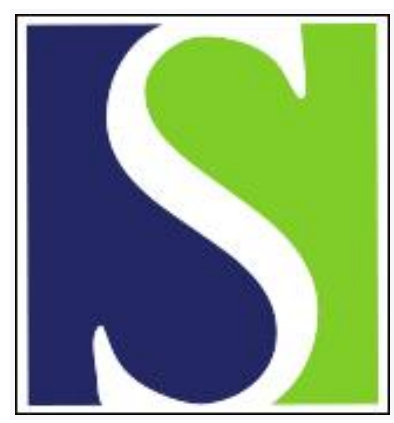

Scand J Work Environ Health 2013;39(6):609-617

https://doi.org/10.5271/sjweh.3373

Published online: 28 Jun 2013, Issue date: 01 Nov 2013

Regional differences in disability retirement: explaining between-county differences in Finland

by Laaksonen M, Gould R

Statistics show large area differences in disability retirement but the contribution of medical causes/explanations for these differences is little studied. We found nearly twofold difference in the incidence of disability retirement between Finnish counties. Differences were largest in retirement due to cardiovascular and musculoskeletal diseases. Demographic structure, work-related characteristics, and area-level characteristics contribute to these differences.

Affiliation: Finnish Centre for Pensions, Fl-00065 Eläketurvakeskus, Helsinki, Finland. mikko.laaksonen@etk.fi

Refers to the following texts of the Journal: 2013;39(2):134-143 2011;37(6):451-453 1997;23(6):403-413

Key terms: area; between-county difference; cardiovascular disease; disability; disability retirement; Finland; Finland; mental disorder; municipality characteristic; musculoskeletal disease; prospective cohort study; regional difference; work-related factor

This article in PubMed: www.ncbi.nlm.nih.gov/pubmed/23807617

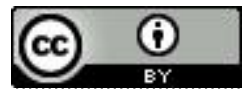




\title{
Regional differences in disability retirement: explaining between-county differences in Finland
}

\author{
By Mikko Laaksonen, PhD, ${ }^{1}$ Raija Gould, PhD ${ }^{1}$
}

\begin{abstract}
Laaksonen M, Gould R. Regional differences in disability retirement: explaining between-county differences in Finland. Scand J Work Environ Health. 2013;39(6):609-617. doi:10.5271/sjweh.3373

Objectives This study aimed to examine between-county differences in disability retirement due to main diagnosis groups and explain these differences by individual-level demographic and work-related factors and municipality-level characteristics.
\end{abstract}

Methods A 20\% random sample of the Finnish social insured population aged 25-62 years at the end of 2006 was followed for disability retirement until the end of 2011. Individual-level demographic and work-related covariates were derived from the registers of the Finnish Centre for Pensions and complemented by municipalitylevel covariates from the national SotkaNet databank. Standardized disability retirement rates were calculated and logistic regression analysis was used to examine between-county differences during the 5-year follow-up.

Results In the county with the highest incidence, disability retirement was nearly twice as common as in the county with the lowest incidence. The between-county differences were larger in disability retirement due to cardiovascular and musculoskeletal diseases than other causes. Adjusting for demographic and work-related characteristics explained a third of the differences. Further adjustment for municipal characteristics explained up to $60 \%$ of the differences. However, in regions of Northern and Eastern Finland with the highest incidence of disability retirement, 20-30\% excess incidence remained even after all adjustments.

Conclusions Large differences exist in disability retirement between Finnish counties. Disability retirement due to musculoskeletal diseases has the highest impact on the overall differences. Demographic structure and work-related characteristics but also municipality-level characteristics contribute to these differences.

Key terms area; cardiovascular disease; mental disorder; musculoskeletal disease; prospective cohort study; work-related factor; municipality characteristic.

In recent years increasing attention has been paid to rapid population aging, which leads to a larger proportion of retirees compared to active employees. Increasing the average retirement age has been considered crucial to ease pressures on social security and welfare systems due to an aging population (1-3). Disability retirement often occurs at relatively young age and considerably lowers the effective retirement age. In Finland, more than 20000 employees retire due to disability each year, which corresponds to nearly one third of all retirees. In 2011, the average age of disability retirement was 53 years among both men and women (4). Postponing disability retirement thus is an important component among the possible measures of increasing retirement age.

Understanding the variation in disability retirement rates across population groups may reveal possibilities for effective targeting of the means aimed at reducing disability retirement. Previous research has shown that the risk of disability retirement varies by characteristics such as age and gender $(5,6)$ as well as occupational class and various work-related factors $(7,8)$. However, remarkably little attention has been paid to differences between geographical areas, even if large variation has been described between regional entities such as provinces or counties and between urban and rural municipalities $(9,10)$. For instance, between Finnish counties the proportion of disability pension recipients of the population aged 16-64 years varied from 4.6 to $11.0 \%$, while the average was $7.3 \%$. Between municipalities the proportions ranged from less than 4 to $20.1 \%$ (11). With respect to the aim of increasing the retirement age, these differences also need attention.

\footnotetext{
${ }^{1}$ Finnish Centre for Pensions, Helsinki, Finland
}

Corresponding author: Mikko Laaksonen, Finnish Centre for Pensions, FI-00065 Eläketurvakeskus, Helsinki, Finland. [E-mail: mikko. laaksonen@etk.fi] 
Studies that have examined regional differences in disability retirement are few. A study comparing 24 municipalities in Nord-Trøndelag county in Norway found a clear geographical pattern with age-standardized disability retirement rates around 80 in the eastern inland regions and as high as 135 in the western and coastal regions. In the areas of high disability retirement rates, typical sources of income were fishing and industrial work while the areas of low prevalence included areas characterized by forestry and agriculture as well as more urban municipalities (12). In a study including a 50-66-year-old population in 25 administrative areas of Oslo, the prevalence of disability retirees varied from $6-42 \%$ among men and $11-42 \%$ among women. Aggregate-level analysis of the data showed that low education, unemployment, and single parenthood were strongly correlated with the disability retirement rate in the area (13). A study examining the incidence of disability retirement due to mental disorders in six southern regions of Norway found that the incidence varied from 22-29 per 10000 inhabitants among men and from 25-32 per 10000 inhabitants among women. Controlling for the amount of psychiatric healthcare staff and the number of psychiatric hospital beds in the region decreased the risk of disability retirement due to mental disorders in some areas and increased it in others compared to the whole of Norway (14).

Previous studies on regional differences in disability retirement have focused on limited geographical areas and been fairly descriptive. Individual factors that are known to affect disability retirement include age, socioeconomic factors, working conditions and health status. Regional differences in disability retirement may arise from differences in composition of the population structure in the areas. However, also contextual factors, which are not reducible to the characteristics of the residents such as economic structure and availability of health services in the area, may affect disability retirement rates. We used nationwide individual-level register data to examine between-county differences in disability retirement and explanations for these differences in Finland.

The aims of this study were to: (i) examine betweencounty differences in disability retirement due to main diagnosis groups, and (ii) explain these differences by individual-level demographic and work-related factors and municipality-level factors.

\section{Methods}

Data

We used a $20 \%$ random sample of the social insured population living in Finland at the end of 2006. The sample was restricted to 25-62-year olds with no prior old-age retirement and who were not on disability retirement at the end of 2006. The sample was followed-up for the first disability retirement after the beginning of 2007 until the end of 2011. Those who had their $63^{\text {rd }}$ birthday, retired due to old age or some early retirement pension scheme, or died were censored. The data included 502819 persons of whom 22130 retired during the follow-up. The mean follow-up time was 4.6 years.

Area classification was based on counties, which are based on historical provinces of Finland. The main tasks of the counties are regional planning and development of enterprise and education, and they serve as forums of cooperation for the municipalities of the area. We use the current area classification where Finland is divided into 19 counties as the municipal-level data was available on this classification.

Data on retirement was based on the Finnish Centre for Pensions (ETK) database including retirements from the earnings-related retirement system. The data did not include disability retirement from the national pension scheme intended for those who have never been in the labor force or providing supplementary income for those with very short working careers. However, nearly all retirees in the age-group studied have earnings-related pensions. In the earning-related pensions system, a partial disability pension can be granted to those 18-62year olds whose work ability is reduced $\geq 40 \%$ while a reduction for $\geq 60 \%$ entitles a full disability pension. If the retiree's work ability can be expected to be restored through treatment or rehabilitation, a temporary disability pension is granted. In this study, both temporary and permanent disability pensions and both partial and full disability pensions were included. The primary medical diagnosis of the retirement was classified according to the International Classification of Diseases, Revision 10 , (ICD-10) into retirements due to mental disorders (ICD-10 Chapter F, 6627 retirees), musculoskeletal diseases (ICD-10 Chapter M, 7681 retirees), cardiovascular diseases (ICD-10 Chapter I, 1723 retirees), and other diseases (6388 retirees).

\section{Explanatory variables}

Data on explanatory variables was based on the year 2006. Demographic variables included age (classified in 5-year-age groups), gender, marital status (living alone/ with another adult), and educational level. Educational level was derived from Statistics Finland and classified into those with basic schooling or no qualifications, and lower-secondary, upper-secondary, and tertiary education (15). Work-related factors included duration of the working career, experience of unemployment, and working sector. The duration of the working career was calculated from non-overlapping employment contracts 
and classified into quintiles. Experience of unemployment during 2006 was classified as no unemployment, and $<1$ month, $\leq 6$ months, and $>6$ months of unemployment. Working sector was classified as self-employed if the person had any entrepreneur's insurance in 2006, and the rest were classified as working in the private sector $>50 \%$, working in the public sector $>50 \%$, and outside the labor force.

Municipality-level variables were derived from the Sotkanet indicator bank (www.sotkanet.fi) maintained by The National Research and Development Institute for Welfare and Health (THL). The Sotkanet databank contains publicly available statistical information on various topics concerning welfare and health collected from municipal registers. The variables used in this study included the proportion of Swedish speakers, the proportion of low-income inhabitants (OECD equalized income $<60 \%$ of the median), the proportion of unemployed of the workforce, and the proportion of single parent families of all families with children. Furthermore, the proportion of inhabitants aged 25-64 years who had received sickness allowance for $\geq 1$ day after a 9-day waiting period was used as a measure of overall morbidity. All municipality-level variables were based on 2006 data and classified into quintiles.

\section{Statistical analysis}

The incidence of disability retirement during the followup was first calculated for each county. The incidence is described per 1000 person-years. We then derived the indirectly standardized disability retirement rates using the age-specific disability retirement rates from the whole country to derive expected numbers of retirees in each county. Comparing these figures to those observed shows how much the disability rate in the county differs from the country average. The standardized rates were derived for all causes of disability retirement and separately for mental disorders, musculoskeletal diseases, cardiovascular diseases, and other causes of disability retirement. Coefficient for variation was calculated to summarize the variation between counties.

Logistic regression analysis was applied to analyze explanations for the county differences. We first adjusted for the individual-level demographic and work-related variables and then the municipal-level explanatory factors. The county of Uusimaa, the most urbanized and largest county measured by the number of inhabitants, was used as the reference category. To get an overall estimate of the between-county variation and its change when adjusting for the explanatory variables without having to use any reference category, we also conducted the corresponding random effects models with the same explanatory variables. County was used as a random variable and all other covariates as fixed effects. To increase comparability with the above analyses, the between-county variance was translated into odds ratio scale $(16,17)$. The median odds ratio (MOR) quantifies the county-level variation by comparing persons with same covariate values in any two randomly chosen counties. The MOR represents the median value of the odds ratio between the area with the higher risk and the area with the lower risk for disability pension. The analyses were conducted using SAS 9.3 software (SAS Institute, Cary, NC, USA).

\section{Results}

The overall incidence of disability retirement was 9.56 per 1000 person years. Clear differences were seen between the counties (figure 1 and table 1). After adjustment for age, the lowest incidence was found in the counties of Ahvenanmaa, Uusimaa, and Pohjanmaa. In the counties of Kainuu, Lappi, Pohjois-Savo, and Pohjois-Pohjanmaa the incidence was nearly twice as high as in the counties of the lowest incidence.

Table 1 shows the standardized disability rate divided into the main diagnostic groups of disability. The country average is denoted by 100 , and any difference from that figure shows the percentage difference from the average within the disease category. For example, Uusimaa had 21 percent lower incidence of disability retirement than was expected under the assumption

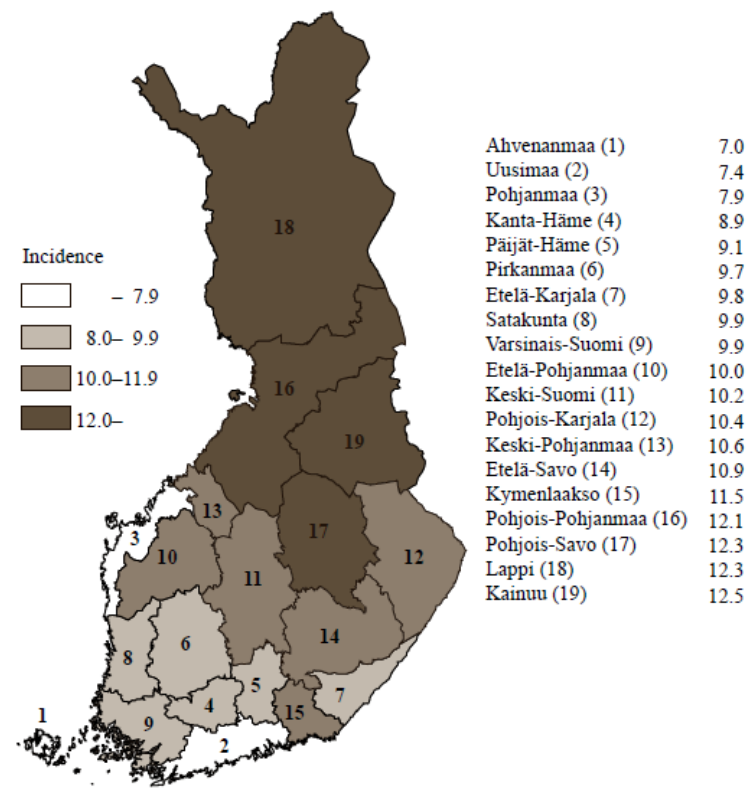

Figure 1. Age-adjusted incidence of disability retirement by county (per 1000 person-years). 
that within each age group the disability retirement rate would be the same as in the whole country. The diagnosis specific results show that the between-county differences were larger in disability retirement due to cardiovascular and musculoskeletal diseases than mental disorders and other diseases. Disability retirement due to cardiovascular diseases was particularly high in KeskiPohjanmaa, Kainuu, Lappi, and Pohjois-Pohjanmaa. It was particularly low in the counties of Ahvenanmaa, Pohjanmaa, and Uusimaa, and in the southwestern counties of Satakunta and Varsinais-Suomi. The county of Pohjois-Savo had up to 54\% higher disability retirement rate due to musculoskeletal diseases than expected while the rate of Uusimaa was 36\% lower. Again, high incidence was also seen in Pohjois-Pohjanmaa, Lappi, and Kainuu. For mental disorders, the between-county differences were narrower. However, low incidence was again seen in Ahvenanmaa and Pohjanmaa, as well as in Kanta-Häme and Päijät-Häme. In the heterogeneous category of other causes of disability retirement, the differences were also more narrow. However, the lowest incidences were found in the same areas as for the other disease categories.

We further examined potential individual- and municipality-level explanations for the between-county differences in all-cause disability retirement. Distribution of the explanatory factors by municipality is presented in the appendix (supplementary table A). After having been adjusted for age, the odds for incident disability retirement was 1.6 times higher in PohjoisPohjanmaa, Kainuu, Lappi, and Pohjois-Savo than in the reference county of Uusimaa (table 2). Adjusting for other demographic factors (gender, marital status, and educational level) attenuated the association by nearly one fifth, judging by the reduction in the MOR. Adjusting for work-related factors (career length, unemployment experience, and working sector) attenuated these associations even slightly more. When both demographics and work-related factors were adjusted for simultaneously, a slightly stronger effect was seen. We then adjusted for the municipality-level factors to see whether they had influence on top of the individual level factors. Again, adjusting for municipality level factors further attenuated the association. Municipality level sickness absence slightly attenuated the association on top of all prior adjustments (also slightly increased in some areas, compared to Uusimaa). About $60 \%$ of the between-county variance was explained by these factors. However, in some areas the risk of disability retirement remained statistically significantly higher than in the reference area. In particular, in Keski-Pohjanmaa and Pohjois-Pohjanmaa, but also in Kainuu and Lappi, the effect of the adjustments was somewhat smaller than elsewhere.

\section{Discussion}

We found clear between-county differences in disability retirement in Finland. In the county with the highest incidence, disability retirement was nearly twice as common as in the county with the lowest incidence. Differences in disability retirement due to cardiovascular and

Table 1. Standardized disability retirement rate according to main diagnostic group of retirement by county

\begin{tabular}{|c|c|c|c|c|c|c|c|}
\hline & \multirow[t]{2}{*}{$\mathrm{N}$} & \multirow{2}{*}{$\begin{array}{l}\text { Disability } \\
\text { retirees }\end{array}$} & \multicolumn{5}{|c|}{ Standardized disability retirement rate } \\
\hline & & & All causes & $\begin{array}{l}\text { Musculoskeletal } \\
\text { diseases }\end{array}$ & $\begin{array}{c}\text { Mental } \\
\text { disorders }\end{array}$ & $\begin{array}{l}\text { Cardiovascular } \\
\text { diseases }\end{array}$ & $\begin{array}{l}\text { Other } \\
\text { causes }\end{array}$ \\
\hline Uusimaa & 152745 & 5062 & 79 & 64 & 90 & 84 & 84 \\
\hline Varsinais-Suomi & 43510 & 1985 & 104 & 104 & 109 & 82 & 105 \\
\hline Satakunta & 20880 & 1006 & 103 & 117 & 92 & 76 & 106 \\
\hline Kanta Häme & 15665 & 666 & 94 & 94 & 83 & 86 & 105 \\
\hline Pirkanmaa & 45526 & 1978 & 102 & 100 & 99 & 107 & 105 \\
\hline Päijät-Häme & 18507 & 831 & 96 & 100 & 86 & 87 & 103 \\
\hline Kymenlaakso & 17101 & 936 & 120 & 131 & 116 & 99 & 116 \\
\hline Etelä-Karjala & 12177 & 581 & 102 & 94 & 115 & 106 & 99 \\
\hline Etelä-Savo & 14006 & 764 & 114 & 135 & 100 & 117 & 99 \\
\hline Pohjois-Savo & 22241 & 1273 & 128 & 154 & 118 & 131 & 105 \\
\hline Pohjois-Karjala & 15033 & 768 & 108 & 117 & 101 & 116 & 103 \\
\hline Keski-Suomi & 24662 & 1169 & 108 & 108 & 105 & 116 & 108 \\
\hline Etelä-Pohjanmaa & 16946 & 815 & 104 & 100 & 106 & 89 & 111 \\
\hline Pohjanmaa & 15891 & 603 & 84 & 88 & 79 & 72 & 86 \\
\hline Keski-Pohjanmaa & 6191 & 312 & 111 & 104 & 96 & 153 & 123 \\
\hline Pohjois-Pohjanmaa & 34770 & 1824 & 126 & 144 & 126 & 140 & 102 \\
\hline Kainuu & 7381 & 453 & 130 & 129 & 114 & 149 & 141 \\
\hline Lappi & 16879 & 1013 & 129 & 137 & 114 & 147 & 129 \\
\hline Ahvenanmaa & 2708 & 91 & 74 & 72 & 75 & 62 & 78 \\
\hline Coefficient of variation & & & 15.5 & 21.8 & 14.3 & 26.3 & 14.0 \\
\hline
\end{tabular}


Table 2. Individual-level and municipality-level explanations for county differences in disability retirement. Odds ratio (OR) compared to Uusimaa county and median odds ratio for any two randomly chosen counties. [ $95 \% \mathrm{Cl}=95 \%$ confidence interval]

\begin{tabular}{|c|c|c|c|c|c|c|c|c|c|c|c|c|}
\hline & \multicolumn{2}{|c|}{ Model $1^{\mathrm{a}}$} & \multicolumn{2}{|c|}{ Model $2^{\mathrm{b}}$} & \multicolumn{2}{|c|}{ Model $3^{c}$} & \multicolumn{2}{|c|}{ Model $4^{\mathrm{d}}$} & \multicolumn{2}{|c|}{ Model $5^{\mathrm{e}}$} & \multicolumn{2}{|c|}{ Model $6^{\dagger}$} \\
\hline & OR & $95 \% \mathrm{Cl}$ & OR & $95 \% \mathrm{Cl}$ & OR & $95 \% \mathrm{Cl}$ & OR & $95 \% \mathrm{Cl}$ & OR & $95 \% \mathrm{Cl}$ & OR & $95 \% \mathrm{Cl}$ \\
\hline Uusimaa & 1.00 & & 1.00 & & 1.00 & & 1.00 & & 1.00 & & 1.00 & \\
\hline Varsinais-Suomi & 1.33 & $1.26-1.40$ & 1.23 & $1.17-1.30$ & 1.30 & $1.23-1.37$ & 1.20 & $1.14-1.27$ & 1.12 & $1.04-1.21$ & 1.08 & $1.00-1.17$ \\
\hline Satakunta & 1.31 & $1.22-1.40$ & 1.16 & $1.08-1.25$ & 1.21 & $1.13-1.30$ & 1.10 & $1.02-1.18$ & 1.00 & $0.89-1.13$ & 1.01 & $0.90-1.13$ \\
\hline Kanta Häme & 1.18 & $1.09-1.28$ & 1.09 & $1.00-1.18$ & 1.14 & $1.05-1.24$ & 1.04 & $0.96-1.13$ & 0.99 & $0.88-1.11$ & 1.01 & $0.89-1.13$ \\
\hline Pirkanmaa & 1.28 & $1.22-1.35$ & 1.18 & $1.12-1.25$ & 1.21 & $1.15-1.28$ & 1.13 & $1.07-1.19$ & 1.05 & $0.95-1.17$ & 1.00 & $0.90-1.12$ \\
\hline Päijät-Häme & 1.21 & $1.12-1.31$ & 1.07 & $0.99-1.15$ & 1.11 & $1.03-1.20$ & 1.01 & $0.93-1.09$ & 0.94 & $0.83-1.06$ & 0.98 & $0.86-1.12$ \\
\hline Kymenlaakso & 1.50 & $1.40-1.62$ & 1.33 & $1.24-1.43$ & 1.38 & $1.28-1.49$ & 1.26 & $1.17-1.35$ & 1.18 & $1.06-1.33$ & 1.12 & $0.99-1.25$ \\
\hline Etelä-Karjala & 1.28 & $1.17-1.40$ & 1.13 & $1.03-1.23$ & 1.16 & $1.06-1.27$ & 1.06 & $0.97-1.16$ & 0.94 & $0.82-1.09$ & 0.98 & $0.84-1.13$ \\
\hline Etelä-Savo & 1.44 & $1.33-1.56$ & 1.29 & $1.19-1.39$ & 1.33 & $1.23-1.44$ & 1.21 & $1.11-1.31$ & 1.09 & $0.95-1.25$ & 1.10 & $0.96-1.27$ \\
\hline Pohjois-Savo & 1.62 & $1.52-1.73$ & 1.48 & $1.39-1.58$ & 1.50 & $1.41-1.60$ & 1.38 & $1.29-1.47$ & 1.23 & $1.08-1.41$ & 1.16 & $1.01-1.34$ \\
\hline Pohjois-Karjala & 1.37 & $1.27-1.48$ & 1.20 & $1.11-1.30$ & 1.20 & $1.11-1.30$ & 1.09 & $1.01-1.18$ & 0.95 & $0.82-1.10$ & 0.99 & $0.85-1.15$ \\
\hline Keski-Suomi & 1.36 & $1.27-1.45$ & 1.23 & $1.15-1.31$ & 1.24 & $1.16-1.33$ & 1.15 & $1.07-1.22$ & 1.02 & $0.89-1.17$ & 1.04 & $0.90-1.19$ \\
\hline Etelä-Pohjanmaa & 1.32 & $1.22-1.43$ & 1.22 & $1.13-1.32$ & 1.28 & $1.19-1.39$ & 1.17 & $1.08-1.26$ & 1.03 & $0.92-1.16$ & 1.00 & 0.8 \\
\hline Pohjanmaa & 1.07 & $0.98-1.16$ & 1.01 & $0.92-1.10$ & 1.07 & $0.98-1.16$ & 0.99 & $0.91-1.08$ & 0.99 & $0.89-1.10$ & 0.94 & $0.84-1.05$ \\
\hline Keski-Pohjanmaa & 1.41 & $1.25-1.59$ & 1.30 & $1.15-1.47$ & 1.35 & $1.20-1.53$ & 1.24 & $1.10-1.40$ & 1.23 & $1.07-1.42$ & 1.13 & $0.97-1.31$ \\
\hline Pohjois-Pohjanmaa & 1.62 & $1.53-1.71$ & 1.50 & $1.42-1.59$ & 1.52 & $1.43-1.60$ & 1.42 & $1.34-1.50$ & 1.26 & $1.11-1.43$ & 1.25 & $1.10-1.42$ \\
\hline Kainuu & 1.63 & $1.48-1.81$ & 1.42 & $1.29-1.58$ & 1.42 & $1.28-1.57$ & 1.29 & $1.16-1.43$ & 1.14 & $0.96-1.35$ & 1.22 & $1.03-1.44$ \\
\hline Lappi & 1.64 & $1.53-1.76$ & 1.44 & $1.34-1.54$ & 1.45 & $1.35-1.56$ & 1.31 & $1.22-1.41$ & 1.18 & $1.02-1.35$ & 1.20 & $1.05-1.38$ \\
\hline Ahvenanma & 0.94 & $0.76-1.16$ & 0.91 & $0.74-1.13$ & 1.03 & $0.83-1.27$ & 0.95 & $0.77-1.18$ & 0.97 & $0.78-1.20$ & 0.88 & $0.70-1.10$ \\
\hline Median odds ratio & 1.15 & $1.13-1.18$ & 1.12 & $1.11-1.15$ & 1.11 & $1.10-1.14$ & 1.10 & $1.09-1.13$ & 1.08 & $1.07-1.10$ & 1.06 & $1.05-1.07$ \\
\hline
\end{tabular}

age-adjusted.

b Model 1+demographics.

c Model $1+$ worked-related factors.

${ }^{d}$ Model $1+2+3$.

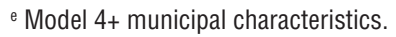

${ }^{\dagger}$ Model $5+$ municipal sickness absence.

musculoskeletal diseases were larger than those due to mental disorders and other diseases. Additional analyses showed that the between-county differences were slightly larger for disability retirement due to depression and other affective disorders than all mental disorders. Other mental disorders include more serious illnesses that often emerge in young adulthood, and therefore may not be so much affected by one's living environment. Smaller variation in disability retirement due to other diseases is plausible as the category is heterogeneous, and even if disability retirement due to one disease in some specific area would be highly prevalent, its effect tends to even out when combined with other reasons.

Several counties showed particularly low or high incidence of disability retirement irrespective of the diagnostic group. In Ahvenanmaa, Pohjanmaa, and Uusimaa, the incidence of disability retirement was low in every diagnostic group examined. Correspondingly, in Pohjois-Savo, Pohjois-Pohjanmaa, Kainuu, and Lappi, disability retirement was more common than expected, irrespective of the diagnosis. However, the differences tended to be more pronounced in disability retirement due physical reasons. This may be related to differences in economic and industrial structures between the areas. In eastern and northern parts of Finland, occupations that include physically heavy work tasks may be more prevalent. Only few counties stood out as areas where the overall incidence of disability retirement was primar- ily elevated by one disease category only, such as EteläSavo where disability retirement due to musculoskeletal diseases was common and Keski-Pohjanmaa with a high incidence of disability retirement due to cardiovascular diseases.

Even if Uusimaa, Pohjanmaa, and Ahvenanmaa performed well throughout, the underlying reasons for this good performance may nevertheless be different. A finer examination revealed that in the most urbanized area of Uusimaa, disability retirement due to musculoskeletal diseases was particularly rare, whereas disability retirement due to cardiovascular diseases was uncommon in Pohjanmaa and Ahvenanmaa. County differences may be partly influenced by selective migration; this may have affected particularly Uusimaa, which has long gained new residents from other parts of the country. On the other hand, the advantageous situation of Ahvenanmaa and Pohjanmaa with respect to several health outcomes has been observed in various studies (18). These areas are inhabited by a relatively well-off Swedish-speaking minority (see appendix table A) but the health advantage has not been reducible to individual-level demographic characteristics. A previous study found significantly higher disability-free life expectancy in bilingual than Finnish-speaking municipalities on the coast of Pohjanmaa (19). In the bilingual municipalities, the average age of disability retirement was higher among the Swedish than Finnish speakers in the same 
municipalities or Finnish speakers living in entirely Finnish-speaking municipalities further south along the coastline. Possible explanations include genetic and cultural differences, such as better social support and networks, but definite conclusions about the reasons for the consistent advantage with respect to different health in these areas have not been reached.

Since disability retirement always requires a specific medical diagnosis, it is plausible that the observed area differences in disability retirement reflect health differences between the areas. It is therefore interesting to compare how these results correspond to those received with other health measures. Mortality is an indicator that has long been used to examine regional health differences in Finland. Even if mortality in general has considerably declined over time, clear differences between areas have persisted (20). Life expectancy in the western coastal areas and in Ahvenanmaa is about four years longer among men and 2-3 years longer among women than in Eastern Finland. Cardiovascular diseases, accidents, violence, and alcohol-related causes of death contribute most to these differences. However, in Uusimaa, life expectancy is not particularly high as there are also areas with very high mortality within the county (21). It is thus interesting to note that even if the main medical causes of disability retirement are very different from those of mortality, the regional differences in these measures are predominantly similar.

In other health-related outcomes, regional differences are not fully consistent but often tend to repeat similar East-West pattern as is seen in mortality. The national Health 2000 survey found slightly better selfrated health and less chronic illnesses in southern Finland than elsewhere. There were no regional differences in mental health problems and even less musculoskeletal problems in Northern Finland than elsewhere (22). Another Finnish survey tends to produce largely similar findings (23). However, more severe mental health problems may be more common in Northern and Eastern Finland (24) and the number of sickness absence days due to mental disorders and musculoskeletal diseases are higher in Eastern and Northern Finland (25), which suggests that more severe forms of mental and musculoskeletal problems are more common there.

The regional differences in disability retirement are broadly similar to the differences in self-evaluated work ability (26). In a study based on the Health 2000 survey, Finnish municipalities were cross-classified into six groups based on their geographic location (Western Finland, Eastern and Northern Finland, and Southern Finland) and whether they were urban or non-urban municipalities. Among women, those who lived in urban municipalities in southern Finland reported the best work ability, whereas among men those who lived in southern Finland, regardless of the type of municipality, had the best work ability. Differences between the other regions were small, but men in Eastern and Northern non-urban municipalities had poorer work ability than those in other regions.

Age and other demographic characteristics partly explained the differences as the demographic composition of the population in the areas with the highest disability retirement incidence was less advantageous. Work-related factors also explained the differences, and further attenuation was seen after simultaneous adjustment for demographics and work-related factors. In addition to individual-level factors, the effect of some municipal characteristics was also examined. Indicators such as the proportion of low-income inhabitants and the proportion of single-parent families were considered as measures of social and material deprivation. Furthermore, the sickness absence level of the municipality was included as a measure of area-level morbidity. Both slightly attenuated the between-county differences in disability retirement after several individual-level characteristics had been controlled for. Previously a lot of research has been done concerning the association between social or material deprivation and poor health. Many studies have found associations between arealevel measures of deprivation with morbidity (27) and mortality (28) independently of individual-level characteristics. However, studies focusing on disability retirement or work ability are few. A Norwegian study found that a small but statistically significant proportion of the risk for disability pension could be attributed to the municipality of residence (29). A UK study found that area deprivation was associated with physical functioning but the association between area deprivation and mental functioning was weak (30).

In addition to the municipality-level factors that we could take into account in our study, also healthcare services, rehabilitation, and employment services could affect area differences in disability retirement, although research evidence of their effect is scarce. In previous research, different access to psychiatric healthcare has been suggested as a possible reason for regional differences in disability retirement due to mental disorders $(14,31)$. A Finnish study suggested that treatment practices and attitudes toward patients may affect differences found between hospital districts in disability retirement after diagnosis for schizophrenia (32). Another study from the one hospital district found notable differences between municipalities in the use of rehabilitation services (33). It is possible that such differences exist also between counties and contribute to the differences observed in this study. We found that even after all adjustments, disability retirement rates remained elevated in Northern and Eastern Finland where sparsely populated areas are typical. In such areas, labor market opportunities are less varied, and 
new working possibilities may not turn up if old jobs die out, which may affect assessment of employment opportunities. There may also be differences between regions in employment opportunities among those with limited work ability.

\section{Strengths and limitations}

Our study was based on large and nationally representative data with no loss to follow-up. However, the selection of potential explanatory variables was limited to variables that are commonly found in registers. For example, measures of health status or exposure to physical or psychosocial working conditions were not available. Some of the explanatory variables were available only at the municipality level, and they are subject to individual-level residual confounding. It is not possible to separate whether these variables affect disability retirement only at the individual level or whether there are also true contextual effects related to these variables. For example, an interesting question regarding the debate on shifting retirement age upwards is whether the findings only reflect county differences in health status and functioning or whether there are area-level factors that affect disability retirement in other ways that could be affected by social and economic policies. In order to answer this question, it would be necessary to properly control for health status at the individual level, but that was not possible in our study.

According to the Finnish disability pension legislation, one's work ability is considered with respect to work that one can reasonably be expected to do, taking into account one's work experience, age, and other circumstances. The legislation is similar across the country. While the initial medical assessment is made by a local physician, the final decision on one's remaining work ability is made centralized in a few insurance institutions to uphold common standards. Thus, it is not likely that local practices in the evaluation of work ability could affect the results.

\section{Concluding remarks}

In summary, analyses based on nationally representative register data showed large between-county differences in disability retirement in Finland. The differences were larger in disability retirement due to cardiovascular and musculoskeletal diseases than due to other causes. Disability retirement due to musculoskeletal diseases in particular has a high impact on the overall differences. Adjusting for demographic and work-related characteristics as well as municipal characteristics explained the differences to a large extent. However, in certain regions of Northern and Eastern Finland, the incidence of disability retirement remained elevated even after all adjustments. More information on the arrangement of local services would be needed to advance our understanding of regional differences in disability retirement.

\section{Acknowledgments}

We would like to thank J Salonen and J Lampi for preparing the data and $\mathrm{H}$ Nyman for her assistance with the figure.

\section{References}

1. Christensen K, Doblhammer G, Rau R, Vaupel JW. Ageing populations: the challenges ahead. Lancet 2009;374(9696):1196-1208. http://dx.doi.org/10.1016/ S0140-6736(09)61460-4.

2. Doyle Y, McKee M, Rechel B, Grundy E. Meeting the challenge of population ageing. BMJ 2009;339:b3926. http:// dx.doi.org/10.1136/bmj.b3926.

3. Härmä M. Adding more years to the work careers of an aging workforce - what works? Scand J Work Environ Health 2011;37(6):451-453. http://dx.doi.org/10.5271/sjweh.3198.

4. Pensioners and Insured in Finland 2011. Official Statistics of Finland, Social Protection. Helsinki: Finnish Centre for Pensions, Keva and the State Treasury; 2013. http://bit. ly/12Tfc00.

5. Karlsson N, Borg K, Carstensen J, Hensing G, Alexanderson $\mathrm{K}$. Risk of disability pension in relation to gender and age in a Swedish county; a 12-year population based, prospective cohort study. Work 2006;27(2):173-179.

6. Krokstad S, Johnsen R, Westin S. Social determinants of disability pension: A 10-year follow-up of 62000 people in a Norwegian county population. Int J Epidemiol 2002;31(6):1183-1191. http://dx.doi.org/10.1093/ije/31.6.1183.

7. Krause N, Lynch J, Kaplan GA, Cohen RD, Goldberg DE, Salonen JT. Predictors of disability retirement. Scand J Work Environ Health 1997;23(6):403-413. http://dx.doi. org/10.5271/sjweh.262.

8. Schuring M, Robroek SJ, Otten FW, Arts CH, Burdorf A. The effect of ill health and socioeconomic status on labor force exit and re-employment: a prospective study with ten years follow-up in the Netherlands. Scand J Work Environ Health 2013;39(2):134-143. http://dx.doi.org/10.5271/sjweh.3321.

9. OECD (Organisation for Economic Co-operation and Development). Sickness, disability and work: breaking the barriers. Vol. 3: Denmark, Finland, Ireland and the Netherlands. Paris: OECD; 2008.

10. McVicar D. Why do disability benefit rolls vary between regions? A review of the evidence from the USA and the UK. Regional Studies 2006;40(5):519-533. http://dx.doi. org/10.1080/00343400600757635. 
11. Tilasto Suomen eläkkeensaajista kunnittain, 2011 [Statistical yearbook of pensioners in Finland by municipality, 2011] Official Statistics of Finland, Social Protection. Helsinki: Finnish Centre for Pensions and The Social Insurance Institution of Finland; 2012. http://bit.ly/12fmsVq

12. Krokstad S, Westin S. Disability in society-medical and nonmedical determinants for disability pension in a Norwegian total county population study. Soc Sci Med 2004;58(10):18371848. http://dx.doi.org/10.1016/S0277-9536(03)00409-X.

13. Rognerud MA, Kruger O, Gjertsen F, Thelle DS. Strong regional links between socio-economic background factors and disability and mortality in Oslo, Norway. Eur J Epidemiol 1998;14(5):457-463. http://dx.doi. org/10.1023/A:1007448120325.

14. Andersson L, Wiles N, Lewis G, Brage S, Hensing G. Can access to psychiatric health care explain regional differences in disability pension with psychiatric disorders? Soc Psychiatry Psychiatr Epidemiol 2007;42(5):366-371. http://dx.doi. org/10.1007/s00127-007-0176-1.

15. Statistics Finland. Finnish standard classification of education 2006. Handbooks 1. Helsinki: Statistics Finland; 2007.

16. Larsen K, Merlo J. Appropriate assessment of neighborhood effects on individual health: integrating random and fixed effects in multilevel logistic regression. Am J Epidemiol 2005;161(1):81-88. http://dx.doi.org/10.1093/aje/kwi017.

17. Merlo J, Chaix B, Ohlsson H, Beckman A, Johnell K, Hjerpe P, et al. A brief conceptual tutorial of multilevel analysis in social epidemiology: using measures of clustering in multilevel logistic regression to investigate contextual phenomena. J Epidemiol Community Health 2006;60(4):290-297. http:// dx.doi.org/10.1136/jech.2004.029454.

18. Saarela J, Finnäs F. Mortality variation by birth region and ethnicity: an illustration based on the Finnish Population Register. Hum Biol 2010;82(1):1-15. http://dx.doi. org/10.3378/027.082.0102.

19. Hyyppä MT, Mäki J. Why do Swedish-speaking Finns have longer active life? An area for social capital research. Health Promot Int 2001;16(1):55-64. http://dx.doi.org/10.1093/ heapro/16.1.55.

20. Martelin T, Koskinen S, Valkonen T. Mortality. In: Aromaa A, Koskinen S, Huttunen J, Teperi J, editors. Health in Finland. Helsinki: National Public Health Institute (KTL), Stakes and Ministry of Social Affairs and Health; 2006. p. 48-51.

21. Kauppinen TM, Valkonen T, Martikainen P. Elinajanodotteen alue-erojen kehitys ja sosiaalisen rakenteen yhteys eroihin pääkaupunkiseudulla (in Finnish) / Förväntad livslängd och social struktur i Huvudstadsregionen (in Swedish) (Life expectancy and social structure in the Capital Region). Kvartti, City of Helsinki Urban Facts 3/2008. p. 30-42.

22. Aromaa A, Koskinen S, editors. Health and Functional capacity in Finland. Baseline Results of the Health 2000 Health Examination Survey. Helsinki: National Public Health Institute; 2004.

23. Helakorpi S, Holstila A, Virtanen S, Uutela A. Suomalaisen aikuisväestön terveyskäyttäytyminen ja terveys, kevät 2011
[Health Behaviour and Health among the Finnish Adult Population, Spring 2011]. Helsinki: THL; 2012.

24. Perälä J, Saarni SI, Ostamo A, Pirkola S, Haukka J, Härkanen $\mathrm{T}$, et al. Geographic variation and sociodemographic characteristics of psychotic disorders in Finland. Schizophr Res 2008;106(2-3):337-347. http://dx.doi.org/10.1016/j. schres.2008.08.017.

25. Kansaneläkelaitos (Social Insurance Institution of Finland). Kelan sairausvakuutustilasto 2012 (Health Insurance Statistics 2012) . Official Statistics of Finland, Social Protection. Helsinki: Kansaeläkelaitos; 2012. https://helda.helsinki.fi/ bitstream/handle/10138/36466/Sava_11.pdf? sequence $=1$.

26. Gould R, Ilmarinen J, Järvisalo J, Koskinen S, editors. Dimensions of Work Ability. Helsinki: Finnish Centre of Pensions (ETK), The Social Insurance Institution (KELA), National Public Health Institute (KTL), Finnish Institute of Occupational Health (FIOH); 2008.

27. Pickett KE, Pearl M. Multilevel analyses of neighbourhood socioeconomic context and health outcomes: a critical review. J Epidemiol Community Health 2001;55(2):111-122. http:// dx.doi.org/10.1136/jech.55.2.111.

28. Meijer M, Röhl J, Bloomfield K, Grittner U. Do neighborhoods affectindividual mortality?Asystematic review and meta-analysis of multilevel studies. Soc Sci Med 2012;74(8):1204-1212. http://dx.doi.org/10.1016/j.socscimed.2011.11.034.

29. Stover M, Pape K, Johnsen R, Fleten N, Sund ER, Claussen $\mathrm{B}$, et al. Unemployment and disability pension-an 18-year follow-up study of a 40-year-old population in a Norwegian county. BMC Public Health 2012;12:148. http://dx.doi. org/10.1186/1471-2458-12-148.

30. Wainwright NW, Surtees PG. Places, people, and their physical and mental functional health. J Epidemiol Community Health 2004;58(4):333-339. http://dx.doi.org/10.1136/ jech.2003.012518

31. Bratberg E, Gjesdal S, Maeland JG. Sickness absence with psychiatric diagnoses: Individual and contextual predictors of permanent disability. Health Place 2009;15(1):308-314. http:// dx.doi.org/10.1016/j.healthplace.2008.06.004.

32. Kiviniemi M, Suvisaari J, Pirkola S, Läksy K, Häkkinen U, Isohanni M, et al. Five-year follow-up study of disability pension rates in first-onset schizophrenia with special focus on regional differences and mortality. Gen Hosp Psychiatry 2011;33(5):509-517. http://dx.doi.org/10.1016/j. genhosppsych.2011.05.017.

33. Pulkki JM, Rissanen P, Raitanen JA, Viitanen EA. Use and distribution of rehabilitation services: a register linkage study in one hospital district area in Finland. Int $\mathrm{J}$ Rehabil Res 2011;34(2):160-166. http://dx.doi.org/10.1097/ MRR.0b013e328344ae33.

Received for publication: 11 February 2013 


\section{Appendix}

Table A. Distribution of the explanatory factors by county

\begin{tabular}{|c|c|c|c|c|c|c|c|c|c|c|c|c|}
\hline & \multicolumn{7}{|c|}{ Individual-level factors } & \multicolumn{5}{|c|}{ Municipal characteristics } \\
\hline & $\begin{array}{c}\text { Age } \\
\text { (mean) }\end{array}$ & $\begin{array}{c}\text { Male } \\
(\%)\end{array}$ & $\begin{array}{c}\text { Married } \\
(\%)\end{array}$ & $\begin{array}{c}\text { Basic } \\
\text { education } \\
(\%)\end{array}$ & $\begin{array}{c}\text { Un- } \\
\text { employed } \\
(\%)\end{array}$ & $\begin{array}{c}\text { Private } \\
(\%)\end{array}$ & $\begin{array}{l}\text { Career } \\
\text { (mean) }\end{array}$ & $\begin{array}{l}\text { Low in- } \\
\text { come } \\
(\%)\end{array}$ & $\begin{array}{c}\text { Un- } \\
\text { employed } \\
(\%)\end{array}$ & $\begin{array}{c}\text { Single } \\
\text { parent } \\
(\%)\end{array}$ & $\begin{array}{c}\text { Swedish } \\
\text { speakers } \\
(\%)\end{array}$ & $\begin{array}{c}\text { Sickness } \\
\text { absence } \\
(\%)\end{array}$ \\
\hline Uusimaa & 42.4 & 49 & 50 & 21 & 11 & 57 & 18.0 & 11 & 7 & 24 & 9 & 10 \\
\hline Varsinais-Suomi & 43.1 & 50 & 53 & 21 & 15 & 52 & 18.9 & 15 & 8 & 21 & 6 & 12 \\
\hline Satakunta & 44.1 & 50 & 57 & 22 & 19 & 51 & 19.8 & 16 & 12 & 19 & 0 & 12 \\
\hline Kanta Häme & 43.7 & 51 & 54 & 21 & 15 & 51 & 19.8 & 13 & 9 & 20 & 0 & 12 \\
\hline Pirkanmaa & 42.7 & 51 & 53 & 19 & 17 & 52 & 18.2 & 14 & 10 & 20 & 0 & 12 \\
\hline Päijät-Häme & 44.1 & 50 & 52 & 23 & 19 & 52 & 19.5 & 17 & 12 & 22 & 0 & 11 \\
\hline Kymenlaakso & 44.2 & 51 & 53 & 21 & 19 & 52 & 19.6 & 15 & 11 & 21 & 1 & 13 \\
\hline Etelä-Karjala & 44.2 & 51 & 53 & 21 & 21 & 49 & 19.3 & 16 & 12 & 21 & 0 & 12 \\
\hline Etelä-Savo & 44.7 & 51 & 53 & 21 & 20 & 44 & 19.6 & 19 & 12 & 19 & 0 & 12 \\
\hline Pohjois-Savo & 43.6 & 51 & 53 & 18 & 20 & 44 & 18.5 & 18 & 12 & 19 & 0 & 14 \\
\hline Pohjois-Karjala & 44.2 & 51 & 53 & 19 & 25 & 43 & 18.4 & 21 & 15 & 19 & 0 & 12 \\
\hline Keski-Suomi & 43.2 & 51 & 53 & 18 & 21 & 47 & 18.1 & 17 & 13 & 18 & 0 & 12 \\
\hline Etelä-Pohjanmaa & 43.9 & 51 & 61 & 20 & 16 & 46 & 19.6 & 15 & 8 & 15 & 0 & 13 \\
\hline Pohjanmaa & 43.4 & 52 & 58 & 22 & 13 & 47 & 19.1 & 13 & 7 & 15 & 51 & 12 \\
\hline Keski-Pohjanmaa & 43.6 & 51 & 62 & 22 & 17 & 45 & 18.8 & 14 & 9 & 14 & 10 & 13 \\
\hline Pohjois-Pohjanmaa & 42.2 & 52 & 56 & 17 & 19 & 48 & 17.3 & 16 & 11 & 17 & 0 & 13 \\
\hline Kainuu & 44.6 & 51 & 54 & 19 & 28 & 45 & 18.4 & 19 & 17 & 18 & 0 & 11 \\
\hline Lappi & 44.2 & 51 & 50 & 19 & 26 & 42 & 17.8 & 17 & 15 & 21 & 0 & 12 \\
\hline Ahvenanmaa & 43.7 & 48 & 47 & 29 & 5 & 40 & 18.8 & 9 & 2 & 20 & 92 & 12 \\
\hline
\end{tabular}

